911.3: 796.5(477)

\author{
XVII - \\ - у утинський \\ ьвівський н ціон льний університет імені в н \\ вул. . орошенк , 41, м. ввів, 79000, кр їн
}

ро н лізов но зн чення низки пр ць польських геогр фів XVII-першої половини ст. як першоджерел з історичної геогр фії личини. х р ктеризов но спектр кр єзн вчих студій д вніх польських геогр фів і р нніх геогр фічних описів личини. озкрито цінність низки геогр фічних тр кт тів XVII-першої половини ст. для суч сних дослідників історичної геогр фії личини.

лючові слов : історичн геогр фія, личин , геогр фічні тр кт ти.

ост новк теми дослідження. руслі кр єзн вчих досліджень геогр фів ьвівського університету ост нніх десятиріч кту льним сьогодні пит нням є н ліз і систем тиз ція різнорідного м тері лу для формув ння цілісної к ртини історичної геогр фії личини. вдяки зусиллям проф. блія т його учнів і послідовників нині у ьвівському університеті сформов н й плідно розвив ється н уков школ історії укр їнської геогр фії, кту лізов но неоціненний пл ст геогр фічних н пр цюв нь цілої генер ції укр їнських геогр фів кінця -першої половини ст. дним з ктульних з вд нь под льших студій львівських геогр фів у цій ц рині, н н ш погляд, $є$ колективн пр ця н д підготовкою фунд мент льного дослідження “сторичн геогр фія личини”. отреб у т кій пр ці, з якої можн було б почерпнути кр єзн вчу інформ цію про дин міку дміністр тивних меж личини минулих століть, зміни геогр фічної к ртини їі з селення, етногеогр фічної моз їки, розвитку поселень, комунік ційної мережі т г лузей господ рської спеці ліз ції тощо, кту льн серед шкільної і студентської молоді, учителів, кр єзн вців, предст вників г лицької інтелігенції.

ш мет - огляд окремих пр ць д вніх польських геогр фів, що ст новлять не бияку цінність як першоджерел $з$ історичної геогр фії личини XVII-першої половини ст.

ит ння вивчення й з лучення в н уковий обіг доробку визн чних учених-геогр фів минулих сторіч посід ють в суспільно-геогр фічних дослідженнях укр їнських н уковців в гоме місце. еред ост нніх вид нь, у яких сформов но теоретико-методологічні з с ди історії укр їнської геогр фії, розроблено систем тику історико-геогр фічного джерелозн вств, хрестом тійно кту лізов но й уведено в суч сний н уковий обіг десятки визн чних імен і н пр цюв нь д вніх г лицьких геогр фів, розкрито предметну сутність суспільно-геогр фічних досліджень укр їнських учених личини в міжвоєнний період, передусім н звемо низку з с дничих пр ць . блія і . ісьт к [1-3, $12,14,15$ т ін.]. н чну ув гу розглядові цього кол пит нь приділено у пр цях . п нського, . ст вного, · р вчук , . ов льчук , . тойк , · ністрянського,

(C) утинський ., 2012 
. овенч к , . л х, . озняк , . укурудзи, . ст вецької, . ітчук , . руль і руль т інших учених [4-11, 13, 16 т ін.].

ерші комплексні геогр фічні тр кт ти з описом земель ольського королівств , до скл ду якого входил й личин , д тов ні поч тком XVII ст. них певний інтерес як літер турні першоджерел з історичної геогр фії личини ст новлять н пис ні л тинською мовою тр кт ти имон т ровольського "Polonia" (1630), "Lavdatio almae Academiae Cracoviensis" [47], "Declamatio contra obtrectatores Poloniae" [46], т кож популярний н прикінці XVII ст. “ еогр фічний збірник” доктор геллонського університету в н орм нкевич [27].

ершою половиною XVII ст. д тов ні розлогіші геогр фічні тр кт ти л тинською й польською мов ми, які містять цінні інформ ційні блоки з історичної геогр фії личини. еред них н пильне вивчення з слуговують, передусім, “ тур льн (природн ) історія королівств ольського” бріеля жончинського [41], “ еогр фія новітня бо вельми корисн ” д-р ум нського [38], “ стини світу” л дисл в юбенського [36], “ еогр фічний збірник” (1746) д-р лтшевич [42], вид н у ьвові “ ивільн геогр фія” онстянтин нявського [53].

еогр фічні тр кт ти другої половини XVII ст. зберегли попередні стилістичні т змістовні к нони землеопису, проте вирізняються 6 г тшим ф ктологічним і передусім цифровим ст тистичним м тері лом про кількість н селення, у тім числі міського, особливості його геогр фічного розподілу, гр рних з нять і куст рних промислів, про поширення м нуф ктур і ф бричної спр ви, розвиток комунік цій тощо. ік ві д ні $з$ історичної геогр фії личини другої половини XVII ст. можемо почерпнути, передусім, 3 “ еогр фічного збірник” зимир оловки [29], “ еогр фії чи опису чотирьох ч стин світу” вл ішер [26], перекл ду з л тини польською мовою тр кт ту имон т ровольського “ пис ольського королівств ” [48], т кож 3 “ пису ольського королівств” еодор ги [56] i “ еогр фічного лексикону” д-р pпінського [31]. ост нньому, зокрем , поміщено короткі відомості про всі н селені пункти личини т їхню людність.

оком 1767 д тов н пр ця . ги “ итяг з польської геогр фіі” [56]. е літер турне першоджерело з історичної геогр фії личини містить опис природних б г тств кр ю, його дміністр тивного поділу, регіон льних і лок льних особливостей господ рської спеці ліз ції через призму опису н селених пунктів. . Г под в ст тистичні відомості щодо кількості й релігійного скл ду н селення, використ в порівняльногеогр фічний метод для відобр ження історико-геогр фічних т етногр фічних рис окремішності лицького кр ю.

p ф . уроп цький 1768 р. перекл в з німецької польською мовою і вид в зн чним тир жем м лозн ний до того геогр фічний тр кт т . . ушінг “ еогр фія ольського королівств і еликого князівств итовського, т кож інших провінцій, до них н лежних" [22]. р кт т ілюструє дет льн к рт , н якій пок з ні головні н селені пункти і комунік ції личини першої половини XVII ст. к джерело ф ктичного м тері лу з історичної геогр фії личини, тр кт т . . ушінг цік вий оригін льними вторськими викл дк ми з геогр фії торгівлі між личиною т іншими землями вропи, обсягу і структури тов рообмінних потоків, ст ну розвитку річкового і гужового тр нспорту, формув ння центрів солепромислу т інших м нуф ктурних промислів тощо.

з включенням личини до скл ду мон рхії бсбургів геогр фічн н ук й освіт в perioнi н були нового імпульсу й суттєво ктивізув лися. 
еогр фія в встро- горській імперії у ст. посіл місце однієї з чільних к демічних н ук і розвив л ся не менш дин мічно, ніж хімія, фізик, мех нік , медицин . еогр фічн освіт того ч су грунтув л ся н кл сичних німецьких геогр фічних тр кт т X XVIII-поч тку ст., що д ли поштовх розвиткові польської т укр їнської геогр фічної н уки.

XVIII ст., поряд з з г льною землеописовою геогр фією і геост тистикою ктивізув вся суспільний інтерес до геогр фії окремих історико-етногеогр фічних скл дових імперії бсбургів. редметом н шої розвідки є, зокрем , под льше формув ння геогр фії королівств личини й олодимирії (Królestwo Galicji i Lodomerii) - 31772 p. окремої дміністр тивної одиниці встрійської імперії.

ершим польським геогр фічним тр кт том, у якому зроблено спробу систем тизув ти різні геогр фічні д ні про суто г лицькі землі, $є$ “ еогр фія бо докл дний опис королівств личини і олодимирії ( еремишль, 1786, 2-е вид ння - ьвів, 1858) . уроп тницького [34]. фунд мент льній моногр фії к демік геллонського університету, к штелян бузького і белзького, гр ф 1788) д но обгрунтов ну відповідь суч сник м н пит ння історичних витоків н зв них королівств - “від д вніх руських князівств”, вон є першим н уковим історико-геогр фічним н лізом розвитку личини як окремого внутрішньо цілісного історико-геогр фічного кр ю від епохи лицько- олинського королівств до нововиокремленої (історично відновленої) у скл ді мон рхії бсбургів дміністр тивної одиниці імперії - оролівств личини і олодимирії.

. уроп тницький дет льно обгрунтув в етимологію н зви новоутвореного королівств , опис в межі личини і олодимирії, простежив віхи формув ння цих земель довкол р нньосередньовічних столиць личини (міст лич і (м. олодимир, нині м. олодимир- олинський).

оногр фію вирізняє дет льний джерелозн вчий н ліз рукописних документів і першодруків про г лицький кр й від р ннього середньовіччя до XVI ст., т кож дет льн обізн ність втор з усім дміністр тивними одиницями і містечк ми личини. о ж до олодимирії, то . уроп тницький вк зув в н рх їчність (книжність) цієї н зви й обгрунтовув в невіддільність цього д внього князівств в природному, історичному й етногр фічному пл ні від вл сне личини впродовж ост нніх сторіч.

ерш ч стин пр ці . уроп тницького присвячен геогр фії освітніх 3 кл дів (c. 11-13) н чолі 3 ьвівською к демією, геогр фії віросповід нь і н ціон льного скл ду н селення, н лізу ст тистики ст нового і вікового скл ду н селення тощо.

д ними . уроп тницького, ст ном н грудень 1785 р. 3 г льн кількість н селення оролівств ст новил 2,797 млн осіб, які н селяли 261 місто, 67 містечок i 6429 сіл [34, с. 14].

руг ч стин моногр фії - цінне першоджерело з історичної геогр фії міст і p йонів личини - присвячен регіон льному огляду дміністр тивних одиниць королівств личини і олодимирії, вон містить розгорнуту геогр фічну х $\mathrm{p}$ ктеристику кожного з 18 циркулів кр ю (у тім числі еремишльського, овківського, ьвівського, родівського, ернопільського, ереж нського, ліщицького, мбірського, трийського, т нісл вівського), їхніх н селених пунктів, гідрогр фії, природних 6 г тств, господ рської спеці ліз ції, історичних п м’яток і м єтностей.

одо інших геогр фічних пр ць другої половини XVIII ст., то цінні відомості 3 геост тистики й історичної геогр фії личини містяться передусім у: 
- “ овітній геогр фії суч сної доби...” роля ирвич - н ведено н ліз місця личини в європейському економічному просторі [58],

- “ ороткому курсі геогр фії, н лекції поділеному” єт н гурчевського - зібр но кту льні ст тистичні д ні з геогр фії н селення і господ рств [37].

першій половині X ст. відбув л ся ктивіз ція процесів євроінтегр ції личини в поліетнічну структуру імперії бсбургів, розвив л ся тр нсєвропейськ торгівля, ускл днюв л ся комунік ційн мереж, поглиблюв л ся регіон льн господ рськ спеці ліз ція, з'являлися вогнищ індустрі ліз ції, розбудовув ли курортну інфр структуру, под льшого поглиблення н були соці льн стр тифік ція н селення, зубожіння селянств , м сові епідемії і голод у неврож йні роки, грогоспод рств переорієнтовув лися н нові (з везені з мерики) сільськогоспод рські культури (передусім, к ртоплю і тютюн), виник ли жв ві колоні льно-переселенські т мігр ційно-трудові потоки н селення всередині імперії... зв ні процеси й інші кту льні виклики суч сності зумовили певну зміну кцентів у ст тистично- і кр єзн вчо-геогр фічних дослідженнях тої доби.

еред низки геогр фічних пр ць першої половини ст. не биякий інтерес як джерел ф ктологічного м тері лу з історичної геогр фії личини ст новлять, передусім, т кі фунд мент льні моногр фії: “ одорожні з м льовки про горщину і личину” муеля редецького [19], “ ловник історично-ст тистично-геогр фічний королівств личини. . . ідомості з г льні” р нцішк ярчинського [43], “" погр фія д вньої ольщі” б рон дв рд ст вецького [40] т “ колиці личини” огуш течинського [49].

дзвич йно б г т н унік льний ф ктологічний м тері л і 3 м льовки 3 життя містечок і сіл личини кінця XVIII-поч тку ст. книг суперінтенд нт й водноч с єв нгельського п стор львівської гром ди . редецького. 1806 по 1812 рр. цей втор регулярно публікув в кр єзн вчі розвідки в “ зеті ьвівській” (н прикл д, “ ро плоди природи і господ рств у личині” [18], “ оди личини”, “ ори личини”, “ огляд н структуру г лицьких земель” тощо), перед тим - н шп льт х періодичних вид нь ідня. г лом його перу н леж ть пон д три десятки кр єзн вчих пр ць, у тім числі фунд мент льні “ одорожні з м льовки про горщину і личину” (1809) т “ одорож у рп ти” (1809) з по-німецьки скрупульозною фікс цією всіх природних особливостей т етнодемогр фічних і етногоспод рських спектів життєдіяльності н селення різних ч стин г лицького кр ю.

моногр фій . редецького можн почерпнути енциклопедичні х р ктеристики геолого-мінер логічної й орогр фічно-л ндш фтної будови г лицьких земель, гідрогр фії, видового обліку рослинності й тв ринного світу, структури земельних угідь, розподілу лісів і орних земель, структури землеволодінь, геогр фії розселення і поселень, етногеогр фії й етногеодемогр фії, с кр льної й поведінково-мент літетної геогр фії, господ рської ст тистики, розвитку торгівлі т ремесел місцевого н селення, геогр фії мінер льно-сировинних ресурсів, гірночодобувної й ф бричної промисловості, рівня життя всіх соці льних ст нів і н ціон льних груп н селення личини (поляки, русини, євреї, німці), т кож гірських етногр фічних груп (бойки, гуцули, лемки, угорські русини, бещ дські гур лі) тощо.

прикл д, ск жімо, лише з вдяки д ним . редецького дізн ємося, що 1808 р. в околицях ьвов вироблено 400 тис. штук торфових брикетів, які експортув ли у пон д дв десятки інших міст личини. . редецький першим серед геогр фів з лишив су- 
ч сним дослідник м дет льні описи перших мет лургійних осередків личини - у ізуні, коле, мольні, овгому (т ще в декількох коп льнях уковини).

г лом же . редецький поділяв ф бричну промисловість личини н три кл си: 1) де сировиною для ф бричного промислу є тв ринницьк продукція, 2) де сировиною для ф бричного промислу є продукція рослинництв , 3) де сировиною для ф бричного промислу є мінер льні ресурси. еру . редецького н лежить перший комплексний економіко-геогр фічний н ліз розвитку в личині всіх різновидів промислового виробництв : від високотехнологічного тк цтв сукн і п волок н модерних нглійських верст т х до промислового розливу лікув льних мінер льних вод.

е меншу цінність ст новить н ліз внутрішньорегіон льної спеці ліз ції рослинництв і с дівництв личини з огляду н геогр фічно-л ндш фтні й грунтово-клім тичні відмінності. . редецький под в ст тистичні відомості щодо обсягу посівів гречки й конопель у східног лицьких повіт х, льону в ередк рп тті, уперше серед н уковців н лізув в причини і н слідки ринкового витіснення тр диційних культур дед лі більшими пл нт ціями тютюну. . редецьким, н поч тку ст. 3 личини до льонск й міст горщини щороку експортув ли до тисячі центнерів тютюну; перші ф брики з обробки тютюнового сирцю функціонув ли в німецьких колоніях окротині, неві й инник х. одо двох н йбільших держ вних ф брик . редецький н вів т кі цифри: ф брик в инник $\mathrm{x}$ щороку перероблял 70 тис. центнерів тютюнового листя і д в л пр цю 885 робітник м, ф брик в он стириськ х - 40 тис. центнерів $і$ д в л пр цю 436 робітник м.

сторичн геогр фія личини - це передусім к рти різних хронологічних зрізів орг ніз ції соціуму. ез мінним першоджерелом для коректного к ртогр фічного відобр ження віх історичної геогр фії кр ю слугує “ погр фія д вньої ольщі” б рон дв рд ст вецького [40]. ній опис но пон д сотню к ртогр фічних джерел XIVXVIII ст., личин є пр ктично н кожній з про н лізов них . ст вецьким ст рожитніх к рт.

р ця “ колиці личини” огуш течинського [49] н пис н в ристокр тичному стилі кл сичних фр нцузьких путівників. е легкі в чит нні історико-кр єзн вчі з м льовки для тих, хто подорожує личиною. втор рекомендув в м ндрівник м відвід ти сл вні героїчним минулим п м'ятк ми рхітектури чи природи містечк й урочищ рідного кр ю. окрем, . течинський р див для відвідин мбір, ур вно, он стириськ, елз, ок ль, ристинопіль, рт ків, овкву, линяни, илятин, лісненськ і ідгірці, лесько, ілий мінь, олочів, уч ч, лич з руїн ми з мку, в силіянський мон стир у рехові, скельний мон стир у озгірче, витоки угу у ерхобужі, сел еняки, окілець і елемін. одорожні з м льовки містять первинну ф ктологічну інформ цію про ст н доріг і придорожньо-гостьової інфр структури, ст н збереженості п м'яток рхітектури, повсякденні з няття і промисли місцевих селян, міжетнічні вз ємини тощо.

еволюційн есн н родів призвел до суттєвих тр нсформ цій суспільно-політичного, ст нового, дміністр тивного й економічного укл ду личини. зв ні тр нсформ ційні процеси, т кож поглиблення теорії і методології європейської геогр фічної н уки зн йшли відобр ження у низці пр ць польських геогр фів т к зв ної нової постреволюційної генер ції. стин 3 них містить цінні інформ ційні блоки з історичної геогр фії личини. окрем , н пильне вивчення з слуговують “ личин з погляду геогр фічно-топогр фічно-історичного” [50] т “ еогр фічно-ст тистичний опис королівств личини й олодимирії” політ тупницького [52], “ пис королівств 

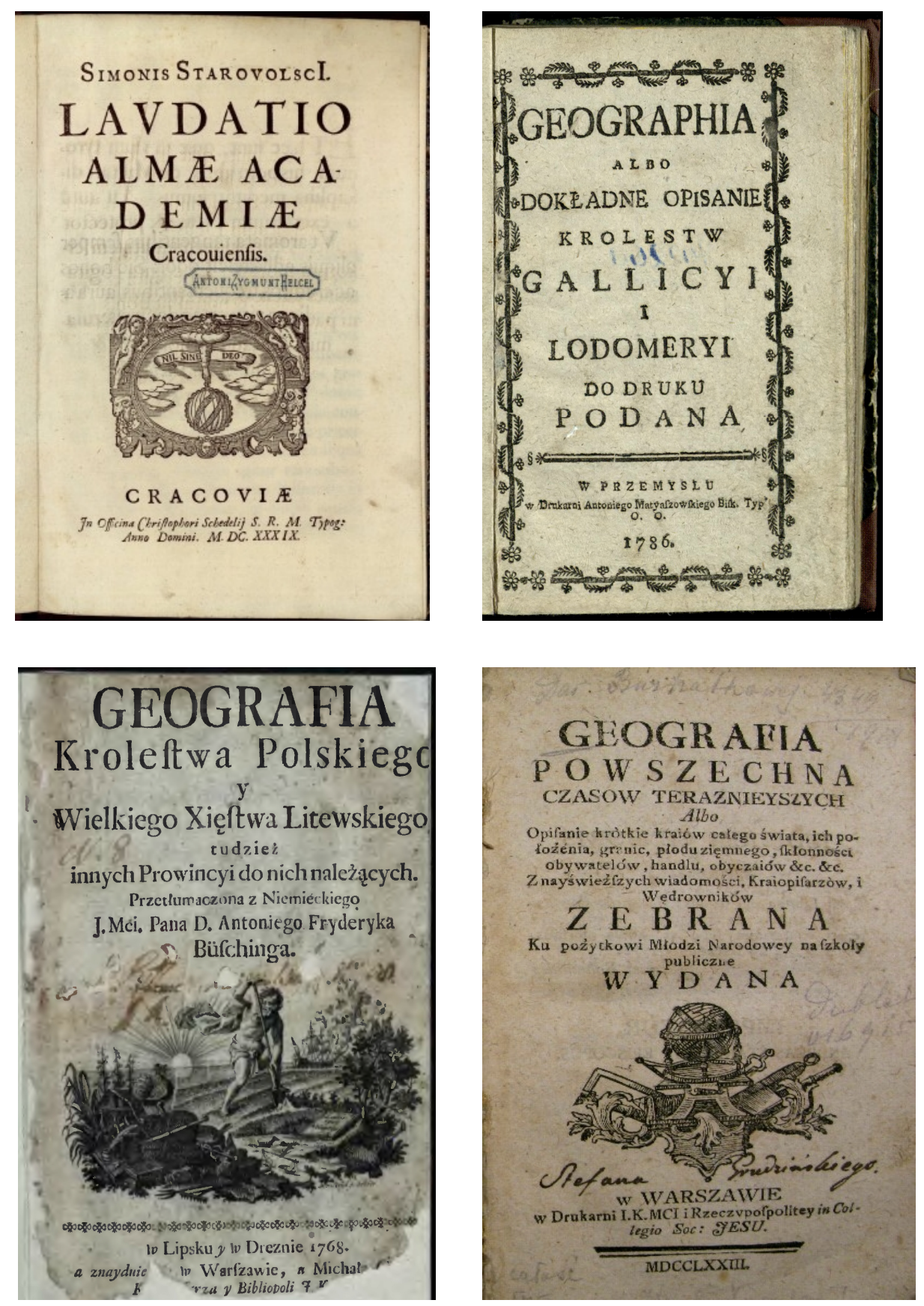

ис. 1. итульні сторінки польських геогр фічних тр кт тів XVII- XVI I ст.: "Lavdatio almae Academiae Cracoviensis” [47], “ еогр фія бо докл дний опис королівств личини і олодимирії [34], “ еогр фія ольського королівств і еликого князівств итовського, т кож інших провінцій, до них прин лежних” [22], “ овітня геогр фія суч сної доби...” [58]. 

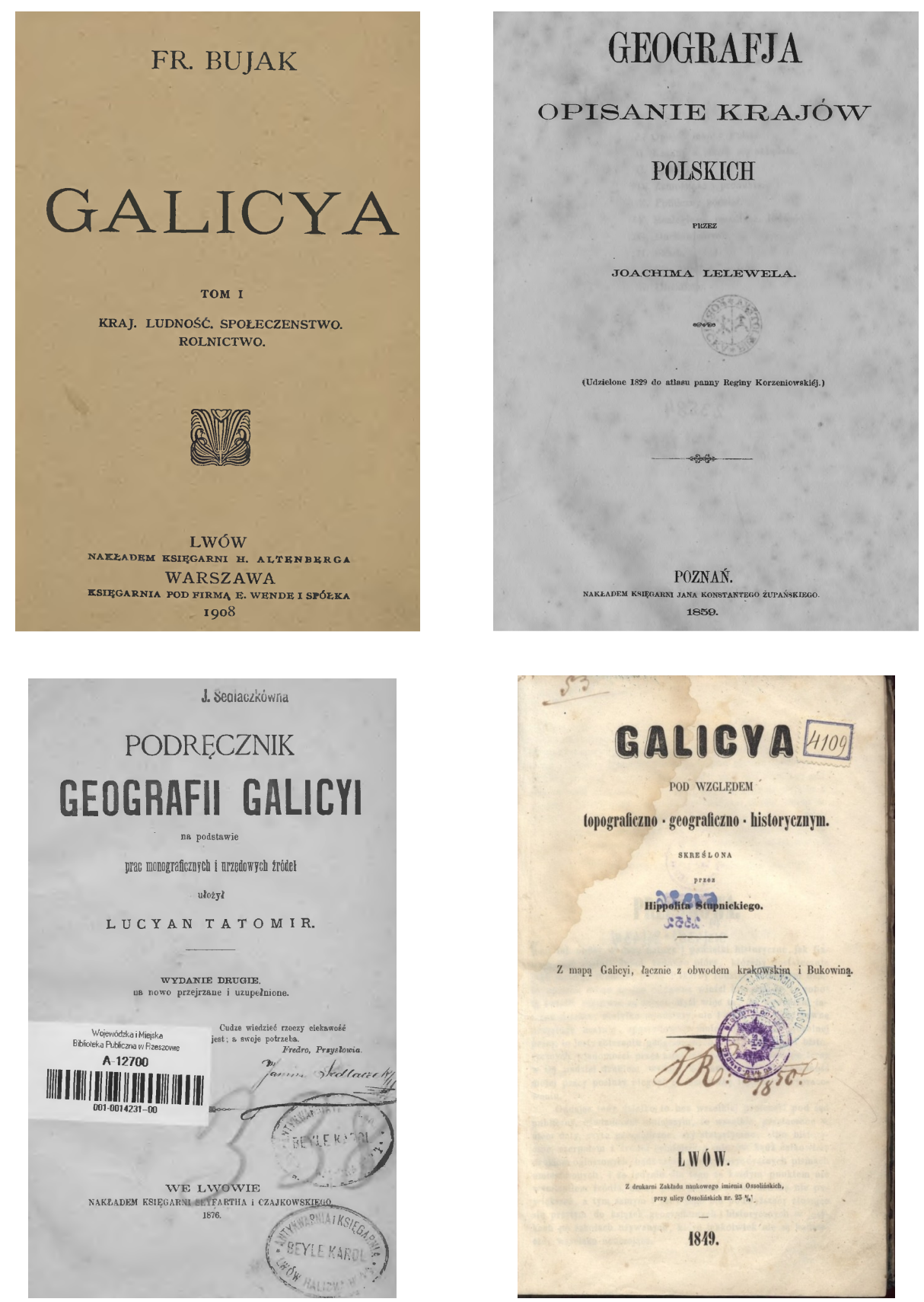

ис. 2. итульні сторінки польських пр ць з геогр фії личини XI - поч тку X ст.: “ личин ” [20], “ еогр фія. пис польських кр в̈в” [35], “ ідручник геогр фії личини н підст ві пр ць моногр фічних і урядових джерел” [55], “ личин 3 погляду геогр фічно-топогр фічноісторичного" [50]. 
ольського з історичного, ст тистичного, рільничого, ф бричного, торгового, побутового й звич євого погляду” зеф ісьліцького [57], “ еогр фія д вньої ольщі” охим иця [54], “ еогр фія. пис польських кр їв” о хим елевеля [35] т “ ідручник геогр фії личини н підст ві пр ць моногр фічних і урядових джерел” уціН томір [55].

й вторитетнішим геогр фом постреволюційної личини другої половини ст. суч сники н зив ли політ тупницького (1806-1878) - втор фунд мент льних геогр фічно-ст тистичних описів личини, відомого львівського гер льдист і вид вця, б г торічного ред ктор львівського н уково-публіцистичного ч сопису "Przyjaciel Domowy".

сь як у вступі до книги “ личин з геогр фічно-топогр фічно-історичного погляду” . тупницький формулюв в суспільну місію історичної геогр фії: “ еогр фію цю поряд з історією присвячую всім гром дян м, які люблять свою вітчизну, і учням шкіл для освіти молоді, дже перш н ук кожної людини від цих підв лин повинн почин тися, для того треб вчитися геогр фії, бо т їй повід $\epsilon$, де і н якій землі вон $є$, т кож історії, бо з неї довід ється, хто вон є! им швидше ці дв поняття прищепимо студенту, тим легше йому й інш н ук піде, і тим певніше він відповід тиме своєму призн ченню, ін кше вся мудрість іноземних фолі нтів не сприятиме його освіті, ле тільки зг сить у ньому любов до б тьківщини” [50, с. 2].

ерший і н йбільший розділ моногр фії м є н зву “ еогр фія личини і олодимирії” (с. 1-97). . тупницький розпоч в його з тлум чення основних топонімів кр ю. окрем , він пис в: “[ оролівство] личину утворено по розборі ольщі: з ч стини лопольщі, уського воєводств , чи т к зв ної ервоної усі ) оділля, б) окуття, с) олодимирії, д) свенцімського і торського князівств , е) пізніше прилучено до неї уковину, ж) в новітньому ч сі прив'яз н р ківськ республік " [50, с. 2].

ртими ув ги є викл дки . тупницького щодо інших широковжив них історикогеогр фічних топонімів кр ю. к от: “ ервон усь обійм л цілу південну ч стину личини між ністром і ном, прозв ну з польського врядув ння уським воєводством, як поділял ся н шість земель: ьвівську, лицьку, ид чівську, еремишльську, ноцьку і елмську. ервоною уссю н зив л ся т ч стин кр ювже з н йпр д вніших ч сів" [50, с. 3].

“ олодимирія, чи олодимирське князівство, обійм л прилеглу до осії землю елмську, уцьку і олодимирську. ід головного для тих земель міст олодимир (н д угом), л тиною "Vlodomeria", н зв олодимирія ( одомерія) пост л . ок ль 3 його повітом у овківському обводі є ч стиною олодимирії” [50, с. 3].

“ ернеїв, 2 км від т нісл вов , в столітті гр д, відомий під н звою ервень, від якого т ч стин усі н зву ервон м л отрим ти. облизу нього олєсл в ривоустий, який н усь проти г лицького князя росл в виступив, поніс через недб лість кр ківського воєводи п м'ятну пор зку" [50, с. 4].

еогр фія личини і олодимирії . тупницького витрим н в кл сичному стилі комплексного геогр фічного опису: від з г льних відомостей і кордонів, тлум чення основних топонімів, покомпонентного природничо-геогр фічного н лізу підстил ючої поверхні, оро- і гідрогр фії, клім ту, грунтів, рослинності й тв ринного світу до етногеогр фії, геогр фії розселення т економічної геогр фії личини. втор н вів усю доступну н 1849 р. ст тистику, н прикл д, релігійну: римо-к толицького визн ння близько 2,43 млн осіб, греко-к толицького - 2,246 млн осіб, пр восл вних - пон д 100 осіб, протест нтів - 38 тис. осіб, іудеїв - 340 тис. осіб, сект нтів близько 400 осіб [50, с. 32]. 
оком 1867 д тов н інш енциклопедично дет лізов н пр ця . тупницького “ еогр фічно-ст тистичний опис королівств личини і олодимирії” ( ьвів, 1867). итрим ний комплексно-геогр фічний принцип опису: геогр фічне положення, орогр фічні, геологічні, гідрогр фічні, клім тичні особливості, рослинність і тв ринний

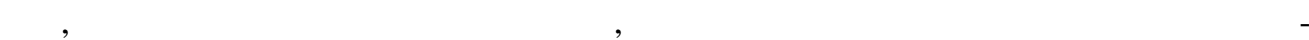
п стуший у гор х. н чн ч стин пр ці присвячен х р ктеристиці дміністр тивної структури і системи розселення, господ рського укл ду і н селення личини, у тім числі окремих етногеогр фічних спільнот (кр ков'яки, гур лі, гуцули, бойки, рівнинні русини т ін.).

. тупницького зн ходимо ргументи н користь історико-етимологічного тлум чення н зв рп ти і ескиди, едобори і ороняки тощо. окрем , 3 . тупницьким, “ зв т [ ескиди] походить імовірно від с рм тського н роду есів, який біля підніжжя тих гір м в м ти свої осідлищ , і де той н род толемей, н йд вніший грецький земелеописув ч, помістив. одібно і луверіус, л тинський хроніст, розуміє під н звою ст рнів н род рпів чи рпі нів, який при пр влінні врелія і іоклеті н 3 лишив свої осідлищ і вирушив у пониззя ун ю, де осів у езії. ід того н роду м $\epsilon$ походити ця н зв н ших рп т" $[52$, с. 6].

о ж до етимології н зви “ личин ”, то . тупницький, попри весь польський п тріотизм, об'єктивно конст тув в: “ зв личини походить від д внього колись просл вленого лицького князівств , яке в столітті було с мостійною держ вою під п нув нням руських князів" [52, с. 27].

“ звич й той кр й, у якому молоко і мед в дост тку плинуть, як к же лугош, м в у д вні ч си в гербі чорну пт ху (г лку) з розпростертими крил ми і золоту корону н білому тлі; як польське воєводство уське - золотого лев н бл китному фоні” [52, с. 26].

дин 3 перших п р гр фів пр ці “ еогр фічно-ст тистичний опис королівств личини і олодимирії” н зив ється “ ічки, озер і мінер льні джерел” (с. 11-16). ньому обгрунтов но головні принципи геогр фічного поширення поверхневих і мінер льних вод личини, под но н ліз низки відомих курортно освоєних джерел через призму їхніх $б$ льнеохімічних вл стивостей.

ижче в регіон льному огляді . тупницький под в короткі відомості про основні курортні центри, що функціонув ли в личині у першій половині ст.: руск вець, оршин, кло, емирів, юбінь еликий, ерче ( нгелів), елятин, уркут, істинь (н осівщині), оршів (н олочівщині), онопківк (н еребовлянщині) т iн.

рті ув ги цифри, н ведені . тупницьким для х $\mathrm{p}$ ктеристики етнічного скл ду

личини: “ юдність кр ю пон д 5 млн душ, з яких близько 4 млн однокорінного походження ( втохтонні мешк нці: поляки і русини).

) оляки (близько 2,25 млн. душ) винятково в з хідній ч стині кр ю, у інших прожив ють зрідк ;

б) усини (близько 2,40 млн. душ) селяни східної ч стини кр ю і околиць гір ж по обвод ндецький, розмовляють руською чи т к зв ною м лоруською мовою і не м ють жодної шляхти відтоді, як п ни і бояри руські прийняли в д вні ч си звич ї і цивіліз цію польську, і н віть римський обряд, розділяючи з польською шляхтою труднощі воєнні і жертви, повністю з нею злилися. род вв ж в їх відтоді як бр тів від однієї м тері. оляки і русини м ли єдину долю, і р зом воюючи проти спільних ворогів, собою $з$ туляли вропу від н в л в рв рств . н обеський і их йло ишневецький, польські королі, були русинського походження" [52, с. 28]. 
е можн оминути т ке геогр фічно-етномент літетне спостереження вченого: “ еляни в з хідній ч стині сильно відрізняються від селян східної ч стини личини. ольський селянин м є жв вий, русин більш мел нхолічний темпер мент; перший з вжди веселий, сміливий і швидкий до бійок, другий н против гу поступливий, розв жливий і смиренний у своєму поступі” [52, с. 35]. “ против гу, руський селянин 3 його поступливістю і розв жливістю вв ж ються більш услужливим і гостинним, будучи призвич єним до в жкої пр ці, любить веселитися у хвилини відпочинку, ле 3 вжди лише в міру [52, с. 36]".

60-ті роки ст. вийшли друком три м сшт бні пр ці з геогр фії ольщі, що містять цінні інформ ційні блоки з історичної геогр фії личини. окрем , це:

- “ пис ольського королівств з погляду історичного, ст тистичного, рільничого, ф бричного, торгового, побутового й звич євого” зеф ісьлицького - містить дет льну економіко-геогр фічну ст тистику вирощув ння й експорту сільськогоспод рських культур, структури виробництв й експорту г лузей обробної промисловості личини, б л нсу її торговельних зв'язків з іншими регіон ми т кр їн ми [57];

- “ еогр фія. пис польських кр їв” о хим елевеля - містить критичну бібліогр фію д вніх описів і м п т порівняльну х р ктеристику природних 6 г тств і демогр фічного потенці лу личини порівняно з іншими польськими провінціями; ув ги в рті порівняльні вторські судження щодо рівнів з можності, виробництв гр рної продукції, обсягів под ткових зборів тощо, н явний м сив ст тистики від 1791 до 1858 років [35];

- “ еогр фія д вньої ольщі” о хим иця - містить д ні щодо просторово-ч сової дин міки дміністр тивно-політичних меж личини, змін її внутрішньої дміністр тивної структури впродовж XV-XVIII ст., розвитку комунік ційної, торгової, ф бричної інфр структури, структури земельного фонду і темпів експлу т ції природних б г тств тощо [54];

к оригін льне літер турне першоджерело історичної геогр фії личини з слуговує н ув жне вивчення принципів і структури викл ду геогр фічного м тері лу перший к демічний “ ідручник геогр фії личини н підст ві пр ць моногр фічних і урядових джерел” уці н томир [55].

орінний львів'янин томир (1836-1901) - ш нов ний у личині пед гог, публіцист, втор перших підручників для гімн зійної і студентської молоді з геогр фії т історії личини (похов ний н ич ківському кл довищі). окрем, . томир н пис в підручники “ еогр фія ольщі” ( ьвів, 1863), “ еогр фія личини” ( ьвів, 1864), “ г льн і ст тистичн геогр фія д вньої ольщі” ( ьвів, 1868), “ гляд ост нніх подорожей і відкрить геогр фічних" ( ьвів, 1869), “еогр фічні з м льовки” ( ьвів, 1877), “ ороткий н рис геогр фії для шкіл” ( ьвів, 1881, спів вт. д-р геогр фії . еноні).

о ершої світової війни підручник ми . томир користув л ся п нівн більшість г лицьких школярів, ліцеїстів, т кож студентів і викл д чів нституту геогр фії ьвівського університету. них “виросл” нов генер ція г лицьких геогр фів (як польських, т к і укр їнських) кінця -поч тку ст.

ерший природничо-геогр фічний блок “ ідручник геогр фії личини...” не втр тив освітньої цінності й сьогодні. ін м є т кі розділи: 1. оложення, протяжність і кордони; 2. ельєф поверхні і геологічн будов (гори і передгір'я; височини і п см горбогір'я; низовини); 3. оверхневі води, б сейни кр ю; 4. лім т і фізіогр фія (л ндш фти - . .) кр ю. ругий суспільно-геогр фічний блок підручник : 5 . оділ кр ю 
н повіти; 6. селення; 7. лоди (мінер льні ресурси; рослинн продукція; тв ринництво); 8. ромисловість; 9. соби комунік ції; 10. оргівля; 11. труктур держ вного упр вління; 12. труктур духовного урядництв ; 13. світ ; 14. успільні орг ні3 ції; 15. м'ятки історії.

оряд зі зг д ними вище, геогр фічну освіту тогоч сної личини розвив в підручник . еноні і . єрського “ еогр фія встро- горської мон рхії”; до 1905 р. його п’ять р зів перевид но у ьвові [17]. одному з регіон льних розділів підручник розкрито місце оролівств личини і олодимирії в системі дміністр тивно-політичного поділу і комунік ційно-господ рської інфр структури поліетнічної імперії бсбургів.

истем тичне геогр фічне вивчення лицького кр ю ктивізув лося після створення в тр вні 1882 р. к федри геогр фії, 1883 р. нституту геогр фії у ьвівському університеті. чолив його, відповідно до ук зу ціс ря встро- горської імперії, проф. тоні ем н. ім'ям . ем н (1840-1917), який керув в нститутом геогр фії з 1883 по 1910 р., пов'яз ний перший період ст новлення геогр фії у ьвівському університеті $[9,14,15]$.

п дщин . ем н й інших вид тних докторів нституту геогр фії ьвівського університету н йповніше вивчен суч сник ми, тому не потребує дет льнішого нонсув ння як джерел історичної геогр фії в р мк х д ної публік ції. кож лише зг д ємо про цінність для суч сних геогр фів у їхніх історико-геогр фічних розвідк х фунд мент льного 15-томного “ еогр фічного словник ольського королівств й інших слов’янських кр їв” [44].

огляду н лімітов ний обсяг ст тті свідомо не н водимо низки (близько сотні джерел другої половини -першої половини ст.) популярної геогр фічно-кр єзн вчої літер тури у форм ті подорожніх нот ток і туристичних путівників личиною. е предмет окремого дослідження. дн к для ілюстр ції того, яку цінність ця груп польських першоджерел ст новить для суч сних дослідників історичної геогр фії личини, зг д ємо одне $з$ т ких свідчень кр янин -очевидця “ ерше вр ження з довшої прогулянки кр єм" [32].

цих нот тк х отгільф ох - ктивний член мбірського пед гогічного тов риств - 3 лишив н м у подорожньому щоденнику-путівнику спр вді унік льні кр єзн вчі м тері ли $з$ життя місцевого н селення (поляків, укр їнців, євреїв і к р їмів), культурної й історико- рхітектурної сп дщини містечок личини 1879 p. контексті туристичної проблем тики з слуговують н ув гу спостереження м ндрівник . ох про ст н тр ктів ьвівщини (від мбор до ок ля) т в но- р нківщини (від олехов до лум ч ), про функціонув ння її перших з лізниць, про ж люгідний рівень сервісу неб г тьох тогоч сних містечкових готелів тощо.

. ох зм люв в подорожні вр ження від відвідув ння руск вця в липні 1879 р., причому одним з перших у літер турі порівняв р зючі відмінності в ритмі життя цього курортного центру, з одного боку, під ч с літнього н пливу рекре нтів, з іншого, - у несезон [32, с. 92-93].

оч ток ст. можемо вв ж ти першим погеєм кл сичного ет пу розвитку геогр фії в личині. p мк х проблем тики цього дослідження ми кцентуємо ув гу лише н кількох в жливих для історичної геогр фії польських літер турних першоджерел х н стику регіон льної економіки й економічної геогр фії. деться про т кі грунтовні пр ці, як “ личин ” і “ кономічний розвиток личини (1772-1914)” . уяк [20, 21] т “ кономічне положення личини перед війною” . і м нд [25]. 
“ личин ” . уяк - це фунд мент льн двотомн моногр фія з регіон льної економіки (з елемент ми соці льної т економічної геогр фії) обсягом пон д тисячу сторінок. ом 1 м є н зву “ $р$ й (геогр фічний опис). юдність. успільство. ільництво”, ом 2 - “ ісівництво. ірничовидобувний промисел. ромисловість і підприємництво".

продовж 20-30-х років ст. з'явилося близько двох сотень геогр фічних пр ць, що стосуються личини, укр їнською, польською, російською і німецькою мов ми. обмежених р мк х цієї розвідки ми кцентуємо ув гу лише н кількох в гомих для історичної геогр фії польських джерел х міжвоєнного періоду. окрем, це “ кономічн геогр фія” . умплович [28], “ кономічн геогр фія зі ст тистикою суч сного життя” . еж к [23], “ кономічн геогр фія польських земель” . іхоцької [24], “ еогр фія ольщі” . рчевського [30] т “ бр з сьогоднішньої ольщі. кти, цифри, т блиці” . льшевич [39]. ожн з н зв них пр ць є цінним першоджерелом з історичної геогр фії личини, оскільки містить н літичні викл дки і синтез м сиву ст тистичного м тері лу щодо розвитку всіх сфер життєдіяльності личини у міжвоєнний період.

тже, побіжний критичний огляд окремих пр ць д вніх польських геогр фів д $є$ уявлення про те, яку н укову цінність як першоджерел з історичної геогр фії личини XVII-першої половини ст. вони ст новлять. оряд з творчою сп дшиною укр їнських геогр фів цього періоду, з зн чен джерельн 6 з є підв линою для под льших студій львівських геогр фів у історико-геогр фічній ц рині. ідним підсумком подібних студій, н н ше перекон ння, м л 6 у перспективі ст ти колективн моногр фія геогр фів ьвівського університету “сторичн геогр фія личини”.

1. $і с ь m \kappa \ldots$ успільно-геогр фічні дослідження укр їнських вчених личини у міжвоєнний період (1919-1939 рр.) : втореф. дис. ... к нд. геогр. н ук: 11.00 .02 / . . ісьт к. - ьвів, 2001. $19 \mathrm{c.}$

2. $і с ь m \kappa \ldots$ р єзн вчі дослідження укр їнських геогр фів у міжвоєнний період / . . ісьт к, . . б блій // сторія укр їнської геогр фії. пец. випуск: р єзн вство. - ернопіль : ідручники і посібники, 2001. - ип. 2 (4). - . 24-29.

3. $і с ь т \kappa \ldots$. . т новлення ьвівської суспільно-геогр фічної школи у міжвоєнний період / . . ісьт к // ьвівськ суспільно-геогр фічн школ у н ціон льному і європейському виміp x (до 60-річчя к федри економічної і соці льної геогр фії ьвів. н ц. ун-ту ім. . p нк ): м тері ли міжн р. н ук. емін ру. - ьвів : ид. центр ім. . р нк , 2005. - .26-36.

4. yn нський . . сторія геогр фії кр їни : моногр фія / . . уп нський. - ьвів : віт, 1997. $-270 \mathrm{c}$.

5. $\mathrm{cm} в е ц ь \kappa$. онцепту льні з с ди побудови н вч льно-методичних посібників т підручників для учнів з геогр фії рідного кр ю// сторія укр їнської геогр фії. пецвипуск: во. - ернопіль : ідручники і посібники, 2001. - ип. 2 (4). - . 53-54.

6. ст вний . . кр їнські етнічні землі : моногр фія / . . ст вний. - ьвів : віт, 1993. $176 \mathrm{c}$.

7. ов льчук . . сторико-геогр фічний н ліз, синтез і прогноз: суть і зн чення для ст новлення геогр фічного укр їнозн вств / . . о ов льчук // тері ли V конгресу іжн р. соці ції укр їністів: оці льно-гум ніт рні н уки. - ернівці : ут , 2004. - .301-312.

8. $p$ вчук . еогр фічні дослідження кр їнських рп т у -першій половині століть: теоретичні т прикл дні проблеми / . р вчук// кр їнськ геоморфологія - ст н і перспективи: м тері ли міжн р. н ук.-пр кт. конф. - ьвів, 1997. - . 128-130.

9. р вчук. ьвівськ геогр фія з 120 років: історія, персон лії, н укові н прями і школи / 
. р вчук // тері ли міжн р. конф. о 120-річчя геогр фії у ьвівському університеті (2426 вересня 2003 року). - ьвів : ид. центр ім. . р нк , 2003. - . 3-16.

10. руль . еогр фо-кр єзн вчі спекти історичного дослідження личини / . руль, . ернюх // сторія укр їнської геогр фії. - ернопіль : підручники і посібники, 2000. - ип. 1. $.57-61$.

11. руль . . р єзн вство: історичн геогр фія: конспект лекцій / 3 ред. . . уп нського / . . руль. - ернівці : , 1999. - 108 с.

12. овітня укр їнськ суспільн геогр фія. рестом тія / поряд. т втор біогр. ст тей проф. блій. - ьвів : ид. центр ім. . р нк , 2007. - 1008 с.

13. овенч $\kappa$. сторичн геогр фія культури: проблеми змісту т р нгув ння одиниць дослідження / . овенч к // сторія укр їнської геогр фії. - ернопіль: ідручники і посібники, 2007. ип. $1(15) .-$. 3-12.

14. блій . . сторико-геогр фічне джерелозн вство / . . блій, . . ісьт к // сторія укр їнської геогр фії. - ернопіль : ідручники і посібники, 2000. - . 2. - . 12-17.

15. блій . . сторичні виміри укр їнської геогр фії / . . блій // сторія укр їнської геогр фії. - ернопіль: ідручники і посібники, 2000. - . 1. - . 7-15.

16. тойко .. еогр фія в ді лозі культур. мість вступу / . . тойко // истув ння теп н удницького. - ьвів : ид-во , 2006. - . 5-40.

17. Benoni K. Geografia monarchii Austryacko-Wegierskiej / K. Benoni, St. Majerski. Wyd. 5. - Lwów, 1905. - $140 \mathrm{~s}$.

18. Bredetzky S. O płodach natury i kunsztów w Galicyi // Gazeta Lwowska. Dodatek do N. 11-14. Lwów, 1811. - S. 3-8.

19. Bredetzky S. Reisebemerkungen über Ungern und Galizien / S. Bredetzky - Wien, $1809-315$ p.

20. Bujak F. Galicy / F. Bujak. - Lwów, 1908. - . . -562 s.; . . -510 s.

21. Bujak F. Rozwój gospodarczy Galicyi (1772-1914) / F. Bujak. - Lwów, 1917. - 630 s.

22. Büsching A.F. Geografia Krolestwa Polskiego y Wielkiego Xięstwa Litewskiego, tudzie innych Prowincyi do nich nale ących / przeło ył na polski A.E. Kuropatnicki. - Lipsk, Drezno, 1768. - 224 s.

23. Cezak J.S. Geografja gospodarcza wraz ze statystyką ycia współczesnego / J.S. Cezak. Wydanie 2-e. - Warsza-wa, 1927. - 352 s.

24. Cichocka Z. Geografja gospodarcza Ziem Polskich / Z. Cichocka. - Warszawa 1929. - 236 s.

25. Diamand H. Poło enie gospodarcze Galicyi przed wojną / H. Diamand. - Lipsk, 1915. - $110 \mathrm{~s}$.

26. Fiszer P. Geografia czyli czterech części świata opisanie / P. Fiszer. - Warszawa, 1759. - 304 s.

27. Formankiewicz J. Geografii kompendium / J. Formankiewicz. - Kraków, 1671 - 84 s.

28. Gumplowicz W. Geografja gospodarcza /W. Gumplowicz. - Warszawa, 1927. - 212 s.

29. Hołówka K.A. Compendium geographicum / K.A. Hołówka. - Kraków, 1757. - 144 s.

30. Karczewski S. Geografja Polski / S. Karczewski. - Warszawa, 1930. - 230 s.

31. Karpiński. Lexikon geograficzny / Karpiński. - Wilno, 1766. - 144 s.

32. Kohn G. Pierwsze wra enia z dłu szej wycieczki po kraju / G. Kohn. - Sambor, 1880. - 164 s.

33. Krawczuk J. Tradycie naukowe polskich i ukrainskich badań geograficznych Karpat Wschodnich // Geografia na przelomi wieków - jednosć w roznorodnosci / J. Krawczuk. - Warszawa, 1999. - S. 46-51. 34. Kuropatnicki E.A. Geografia albo dokładne opisanie królestw Galicyi i Łodomerii / E.A. Kuropatnicki. - Przemyśl: w Drukarni Antoniego Matyaszowskiego, 1786. - 240 s.

35. Lelewel J. Geografja. Opisanie krajów polskich / J. Lelewel. - Poznań, 1859. - 83 s.

36. Łubieński W. Świat we wszystkich cześciach / W. Łubieński. - Wrocław, $1740-160 \mathrm{~s}$.

37. Nagurczewski K. Geogrffja krótka na lekcje podzielona / K. Nagurczewski. - Warszawa, 1782. $147 \mathrm{~s}$.

38. Naumański. Geografia novissima albo wielce po yteczna / Naumański. - Warszawa, 1729. - $126 \mathrm{~s}$.

39. Olszewicz B. Obraz Polski dzisiejszej. Fakty, cyfry, tablice / B. Olszewicz. - Warszawa, 1938. - 255 s. 40. Rastawiecki E. Mappografia dawnej Polski (z katalogu Janockiego) / E. Rastawiecki. - Warszawa, 1846. - $177 \mathrm{~s}$.

41. Rzqczyński G. Historia naturalis regni Polonia / G. Rzączyński. - Sandomir, 1721. - 87 s.

42. Sałtszewicz. Compendium geographicum / Sałtszewicz. - Cracoviae, 1746. - 224 s. 
43. Siarczyński F. Słownik historyczno-statystyczno-geograficzny królestwa Galicyi. T. I. Wiadomości ogólne. Rękopis / F. Siarczyński. - Lwów, 1824. - 122 s.

44. Słownik geograficzny Królestwa Polskiego i innych krajów słowiańskich. - Warszawa: nakł. Filipa Sulimierskiego i Władysława Walewskiego, 1880-1914. - T. 1-15.

45. Śniadecki J. Jeografia czyli opisanie matematyczne i fizyczne ziemi. - Warszawa, 1804. - $266 \mathrm{~s}$.

46. Starovolsci S. Declamatio contra obtrectatores Poloniae / J. Śniadecki. - Cracovia, 1639. - 54 s.

47. Starovolsci S. Lavdatio almae Academiae Cracoviensis / S. Starovolsci. - Cracovia, 1632. - 32 s.

48. Starowolskiego opisanie królewstwa Polskiego / przeło ył na polski Wincenty Gołębiowski. - Wilno, $1765 .-137 \mathrm{~s}$.

49. Stęczyński B. Okolice Galicyi / B. Stęczyński. - Lwów, 1847. - 232 s.

50. Stupnicki $H$. Galicya pod względem geograficzno-topograficzno-historycznym / H. Stupnicki. Lwów, 1849. - $240 \mathrm{~s}$.

51. Stupnicki H. Geografia Galicyi / H. Stupnicki. - Lwów, 1853. - 128 s.

52. Stupnicki H. Geograficzno-statystyczny opis królestwa Galicyi i Lodomeryi. - Lwów, 1867. - 134 s.

53. Szaniawski K.P. Geographia civilis / H. Stupnicki. - Leopoli, 1748. - 88 s.

54. Szyc J.A. Jeografja dawnéj Polski / J.A. Szyc. - Poznań, 1852. - 352 s.

55. Tatomir L. Podręcznik geografii Galicyi na podstawie prac monograficznych i urzędowych źródeł. Wyd. 2-e, prz. i uzup / L. Tatomir. - Lwów, 1876. - $175 \mathrm{~s}$.

56. Waga T. Wyciąg z geografii polskiej: przez Teodora Wagę w roku 1767 skreślonej i ogłoszonej / T. Waga. - Poznań : J.K. upański, 1856. - 274 s.

57. Wiślicki J.M. Opis Królestwa Polskiego pod względem historycznym, statystycznym, rolniczym, fabrycznym, handlowym, zwyczajowym i obyczajowym / J.M. Wiślicki. - Warszawa, 1850 - 360 s.

58. Wyrwicz K. Geografia powszechna czasow teraznieyszych albo Opisanie krótkie krajów całego świata, ich poło enia, granic, płodu ziemnego, skłonności obywatelów, handlu, obyczaiów etc., etc. Z naywiększych wiadomości, Kraiopisarzów i Wędrowników zebrana Ku po ytkowi Młodzi Narodowey na Szkoły publiczne wydana / K. Wyrwicz. - Warszawa, 1768. - 670 s.

m ття: н дійшл до редколегії 06.10.2011 прийнят до друку 20.11.2011

\title{
POLISH PRIMARY SOURCES OF THE HISTORICAL GEOGRAPHY OF GALICIA IN XVII - FIRST HALF OF XX CENTURY
}

\author{
M. Rutynskyi \\ Ivan Franko National University of Lviv, \\ . Doroshenko St., 41, UA - 79000 Lviv, Ukraine
}

The number of works of Polish geographers from XVII-first half of XX century as the primary sources of historical geography of Galicia have been analyzed. The range of regional studies of old Polish geographers and early geographical descriptions of Galicia are characterized. The importance of some geographical values from XVII - the beginning of XX century for the contemporary historical geography researches are shown.

Key words: historical geography, Galicia, geographical values. 


\section{XVII -}

\section{- Утинский}

ввовский н цион льный университет имени в н ул. . орошенко, 41, г. ьвов, 79000, кр ин

ро н лизиров но зн чение ряд трудов польских геогр фов XVII - первой половины в. к к первоисточников по исторической геогр фии личины. х р ктеризов но спектр кр еведческих исследов ний древних польских геогр фов и р нних геогр фических опис ний личины.

скрыто ценность ряд геогр фических тр кт тов XVII-первой половины ных исследов телей исторической геогр фии личины.

лючевые слов : историческ я геогр фия, личин, геогр фические тр кт ты. 